\title{
Australia Antigen in Chronic Hepatitis in Australia*
}

\author{
J. D. MATHEWS, $\dagger$ M.B., B.SC., M.R.A.C.P. ; I. R. MACKAY, $\ddagger$ M.D., F.R.C.P., F.R.A.C.P.
}

\begin{abstract}
Cummary: Of 53 cases of active chronic liver disease $\checkmark$ two were found to be carriers of Australia antigen Au (1)-an elderly woman with typical lupoid hepatitis and an elderly mortuary attendant with serologically atypical active chronic hepatitis. Au (1) was detected also in the serum of 7 out of 20 patients with clinically atypical acute hepatitis-one was an elderly Italian woman, one had hepatitis in the puerperium, and five had a history of transfusion or inoculation. The antigen was not found in 20 typical cases of infectious hepatitis in young people in 86 patients with other diseases. Antibody to $\mathrm{Au}(1)$ was present in only 2 out of 102 patients who had received numerous transfusions.

We conclude, firstly, that $\mathrm{Au}(1)$ antigen is rare in white Australians (in keeping with the low incidence of serum hepatitis in Australia), and, secondly, that Au (1) positivity in hepatitis patients is associated with transfusions and with older age. We suggest that active chronic hepatitis and lupoid hepatitis may follow infection of susceptible individuals with Au (1)-positive hepatitis virus, but persistence of the virus in high titre does not appear to be necessary for chronicity of the disease.
\end{abstract}

\section{Introduction}

The Austrialia antigen $\mathrm{Au}$ (1) has been detected by immunoprecipitation (Blumberg et al., 1965), particularly in serum from patients with serum hepatitis (Prince, 1968a, 1968b; Giles et al., 1969; Turner and White, 1969) and also from some patients with acute infectious hepatitis (Blumberg et al., 1967; London et al., 1969), active chronic hepatitis (Fox et al., 1969; Gitnick et al., 1969; Wright et al., 1969); and leukaemia and Down's syndrome (Blumberg et al., 1968). Blood containing $\mathrm{Au}$ (1) antigen induces hepatitis when transfused (Gocke and Kavey, 1969), and Au (1)-positive sera contain virus-like particles which are agglutinated by anti-Au (1) serum (Bayer et al., 1968; Hirschman et al., 1969); thus Au (1) antigen is presumed to be a component of a virus which can cause acute hepatitis. Two serological types of hepatitis virus exist which differ in incubation period (Krugman et al., 1967); serum from cases of long-incubation-period hepatitis is Au (1)-positive, whereas serum from cases of short-incubation-period hepatitis is Au (1)-negative (Giles et al., 1969). The data of Prince (1968b) indicate that his serum hepatitis antigen is identical with the Au (1) antigen of Blumberg.

A major interest in this unit has been the study of active chronic hepatitis, and particularly the subgroup with multisystem disease and antinuclear antibodies-lupoid hepatitis. In view of suggestions that active chronic hepatitis is perpetuated by a hepatitis virus (Wright et al., 1969), stored and

\footnotetext{
*Publication No. 1375 from the Walter and Eliza Hall Institute of Medical Research, Melbourne, Victoria, Australia. †Pathologist to the Clinical Research Unit. $\neq$ Head of the Clinical Research Unit.

The Walter and Eliza Hall Institute of Medical Research and the The Walter and Eliza Hall Institute
Royal Melbourne Hospital, Melbourne.
}

fresh sera from patients with lupoid hepatitis, active chronic hepatitis, and other hepatic and autoimmune diseases were tested for $\mathrm{Au}(1)$ antigen.

\section{Methods}

Reference sera with Au (1) activity and anti-Au (1) activity were obtained from London (Dr. Yvonne Cossart) and Philadelphia (Dr. B. Blumberg). One hundred and two sera were obtained from Melbourne hospital patients who had received numerous transfusions. Sera from patients with hepatic and autoimmune diseases were obtained from a bank within this unit. These specimens, collected during 1956-69, had been stored at $-20^{\circ} \mathrm{C}$., but most had been occasionally thawed and refrozen. Where possible, three serum specimens were selected for each patient with a diagnosis of lupoid hepatitis (31 patients) or active chronic hepatitis (22 patients); the diagnostic criteria for these diseases were as described by Mackay et al., (1965). The earliest and the latest available and a randomly selected third specimen were chosen. Subsequently additional sera were tested from any patients found to be Au (1)-positive (Table I, group A). One, two, or three recent specimens

TABle I.-Prevalence of Au (1) Antigen

\begin{tabular}{|c|c|c|c|c|c|c|}
\hline \multirow{2}{*}{\multicolumn{2}{|c|}{ Group Surveyed }} & \multicolumn{2}{|c|}{ No. Tested } & \multicolumn{2}{|c|}{ No. Positive } & \multirow{2}{*}{$\begin{array}{l}\text { Per cent. } \\
\text { Positive } \\
\text { Patients }\end{array}$} \\
\hline & & Patients & Sera & Patients & Sera & \\
\hline $\begin{array}{l}\mathrm{D} \\
\mathbf{E} \\
\mathrm{F} \\
\mathrm{G} \\
\mathbf{H} \\
\mathrm{I}\end{array}$ & 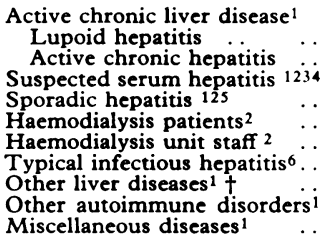 & $\begin{array}{l}31 \\
22 \\
11^{*} \\
6 \\
10 \ddagger \\
22 \\
20 \\
34 \\
18 \\
34\end{array}$ & $\begin{array}{r}97 \\
62 \\
12 \\
6 \\
29 \\
22 \\
20 \\
51 \\
29 \\
35\end{array}$ & $\begin{array}{l}1 \\
1 \\
2 * \\
2 \\
3 \ddagger \\
0 \\
0 \\
0 \\
0 \\
0\end{array}$ & $\begin{array}{r}14 \\
8 \\
2 \\
2 \\
7 \\
0 \\
0 \\
0 \\
0 \\
0\end{array}$ & $\left\{\begin{array}{c}3 \cdot 8 \\
18 \cdot 2 \\
33 \cdot 3 \\
30 \cdot 0 \\
0 \\
0 \\
0 \\
0 \\
0\end{array}\right.$ \\
\hline
\end{tabular}

Sources of sera: ${ }^{1}$ Clinical Research Unit. ${ }^{2}$ Royal Melbourne Hospital. ${ }^{3}$ Blood Transfusion Centre, Perth, Western Australia. ${ }^{4}$ Dr. T. B. Reynolds, Los Angeles, U.S.A. (one case of transfusion hepatitis with evolution to cirrhosis*) Queen Victoria Hospital, Melbourne. ${ }^{\circ}$ Fairfield Infectious Diseases Hospital Victoria.

†Primary biliary cirrhosis. Alcoholic cirrhosis. Haemochromatosis. Cryptogenic

cirrhosis. Wilson's disease.

of serum were selected from patients with other hepatic or autoimmune disorders, including a group of sera from patients with acute hepatitis after inoculation-"suspected serum hepatitis" (group B)-and a small group of adult and elderly patients with acute hepatitis from whom no definite history of inoculation or hepatitis contact was obtained (group C). Twenty-nine sera were collected from 10 patients receiving haemodialysis in the renal unit of this hospital (group D). Specially selected acute-phase sera from 20 children and young adults with typical infectious hepatitis were obtained from an infectious diseases hospital; most gave a history of hepatitis contact (group F). 
Double diffusion was carried out in agarose gel prepared by the method of Prince (1968a). Microscope slides 2.5 by $7.5 \mathrm{~cm}$. were coated with $2.5 \mathrm{ml}$. of gel. Serum samples were placed in holes, $3.5 \mathrm{~mm}$. in diameter, punched in a hexagonal pattern with $7.2 \mathrm{~mm}$. spacing. Slides were kept in a humid chamber at room temperature. Strongly reacting sera gave precipitin lines within 12 to 24 hours which increased in density up to 72 hours. Weaker reactions appeared after 24 to 48 hours. Reactions were read finally after seven days' incubation.

\section{Results}

Occurrence of Anti-Au (1) in Transfused Patients.-Of 102 sera from patients with numerous transfusions, two reacted with serum known to contain $\mathrm{Au}(1)$ antigen-one $(\mathrm{Y})$ from a youth with haemophilia and one (Z) from a man with peptic ulcer, severe gastrointestinal bleeding and acute renal failure. Moreover, these test sera gave reactions of identity with the two reference anti-Au (1) sera. The potency of the local antiserum $(Z)$ was tested by a chequerboard titration against the reference antigen provided by Dr. Blumberg. The two antisera were of the same potency; both gave visible precipitin lines at dilutions of $1: 1$ to $1: 8$, depending on the concentration of the test antigen. In subsequent tests antiserum $\mathrm{Z}$ was used (undiluted) for the detection of antigen.

Patients with Active Chronic and Lupoid Hepatitis.-Of the 53 patients (143 sera tested) with active chronic and lupoid hepatitis, two (six sera) were positive for $\mathrm{Au}$ (1) antigen. Sixteen additional specimens from these two patients were later tested and all were positive. One of these two was an elderly woman with typical lupoid hepatitis, and the other was a mortuary attendant with atypical active chronic hepatitis (see Table II and Appendix).

Table II.-Details of Patients with Positive Reactions for Au (1) Antigen

\begin{tabular}{|c|c|c|c|c|c|}
\hline Group & $\begin{array}{l}\text { Case } \\
\text { No. }\end{array}$ & Sex & Age & Details & Location \\
\hline \multirow[b]{2}{*}{$\mathbf{A}$} & 1 & $\mathbf{F}$ & 71 & $\begin{array}{l}\text { Lupoid hepatitis 1961-9. (see } \\
\text { Appendix, Case 1) }\end{array}$ & C.R.U.* \\
\hline & 2 & $\mathbf{M}$ & 55 & $\begin{array}{l}\text { Mortuary attendant. Active chronic } \\
\text { hepatitis January 1966. (see } \\
\text { Appendix, Case 2) }\end{array}$ & C.R.U.* \\
\hline \multirow[b]{2}{*}{ B } & 3 & $\mathbf{F}$ & 27 & $\begin{array}{l}\text { Blood transfusion June } 1969 . \\
\text { Hepatic encephalopathy August } \\
\text { 1969. Recovered }\end{array}$ & $\begin{array}{l}\text { Perth, } \\
\text { W.A. }\end{array}$ \\
\hline & 4 & $\mathbf{M}$ & 65 & $\begin{array}{l}\text { Hepatitis in December } 1965 \\
\text { following transfusion. Progression } \\
\text { to cirrhosis. Persistence of Au (1) } \\
\text { to } 1969\end{array}$ & $\begin{array}{l}\text { Los } \\
\text { Angeles, } \\
\text { U.S.A. }\end{array}$ \\
\hline \multirow[t]{2}{*}{ C } & 5 & $\mathbf{F}$ & 61 & $\begin{array}{l}\text { Italian immigrant. Infectious } \\
\text { hepatitis of slow onset June } 1968 . \\
\text { Recovery in six weeks with } \\
\text { disappearance of Au (1) }\end{array}$ & C.R.U.* \\
\hline & 6 & $\mathbf{F}$ & 23 & $\begin{array}{l}\text { Hepatitis in puerperium July } 1969 . \\
\text { Hepatosplenomegaly }\end{array}$ & Melbourne \\
\hline \multirow{3}{*}{ D } & 7 & $\mathbf{M}$ & 26 & $\begin{array}{l}\text { Hepatitis March } 1969 \text { with } \\
\text { recovery and disappearance of } \\
\text { antigen in May } 1969\end{array}$ & Melbourne \\
\hline & 8 & $\mathbf{F}$ & 26 & $\begin{array}{l}\text { Hepatitis July } 1969 \text { after detection } \\
\text { of antigen in serum. Persistence } \\
\text { of Au (1) and hepatitis for three } \\
\text { months }\end{array}$ & Melbourne \\
\hline & 9 & $\mathbf{M}$ & 29 & $\begin{array}{l}\text { Mild hepatitis August } 1969 \text { with } \\
\text { recovery and disappearance of } \\
\text { antigen }\end{array}$ & Melbourne \\
\hline
\end{tabular}

*Clinical Research Unit.

Patients with Hepatitis of Various Types.-Two of 11 patients with "suspected serum hepatitis" (group B) gave positive reactions; one of these positive sera came from a patient in Los Angeles who had developed cirrhosis following transfusion hepatitis. Of six patients with atypical acute hepatitis (group C) two gave positive reactions. Three of the 10 patients receiving haemodialysis developed hepatitis and $\mathrm{Au}(1)$ antigen was detected in the serum of all three; in one it was detected two weeks before the onset of hepatitis (group D). Antigen was not detected in serum from any of 22 members of staff of the haemodialysis unit (group E). None of the 20 sera from young patients with typical acute infectious hepatitis (group F) had $\mathrm{Au}$ (1) activity.

Other Hepatic and Autoimmune Diseases.-None of 80 sera from patients with a variety of other liver or autoimmune diseases was positive for $\mathrm{Au}$ (1) (see Table I).

\section{Discussion}

Australia antigen $\mathrm{Au}$ (1) was detected in the serum of one out of 31 cases of lupoid hepatitis (an elderly woman) and in one out of 22 other cases of active chronic hepatitis (an elderly mortuary attendant); this contrasts with prevalences of $10 \%$ and $24 \%$ of $\mathrm{Au}$ (1) positivity in cases of active chronic hepatitis in the U.S.A. (Gitnick et al., 1969; Wright et al., 1969). Of seven other patients in our study whose sera were positive for $\mathrm{Au}$ (1) antigen, five had a history compatible with serum hepatitis, three were patients with renal failure receiving haemodialysis, one was a patient who developed hepatic encephalopathy two months after a blood transfusion, and one patient whose serum was referred from Los Angeles developed cirrhosis after posttransfusion hepatitis. Two $\mathrm{Au}$ (1)positive patients had no inoculation history : an Italian woman aged 61 with atypical acute hepatitis and an Australian woman aged 23 with hepatitis in the puerperium (see Table II). We failed to detect the antigen in a wide range of other hepatic and non-hepatic diseases, including 20 cases of typical acute infectious hepatitis in young people.

In Australia the Au (1) antigen is detected less often in association with acute and chronic hepatitis than it is in the eastern United States and Japan (Okochi and Murakami, 1968; Gocke and Kavey, 1969; Hirschman et al., 1969; London et al., 1969; Wright et al., 1969). This is not attributable to differences in reagents or methods, as the antiserum used in our survey was comparable in sensitivity to that supplied by Dr. Blumberg. Moreover, the findings did not suggest that the antigen had disappeared from our stored sera. The relative rarity of $\mathrm{Au}$ (1) in Melbourne is further shown by the low prevalence $(2 \%)$ of anti-Au (1) antibodies in sera from recipients of numerous blood transfusions. The prevalence of $\mathrm{Au}$ (1) antibody in Great Britain was even lower (Y. E. Cossart, personal communication, 1969). The Australian and British findings are in contrast to the higher prevalences of antibody $(17-28 \%)$ in frequently transfused patients in the U.S.A. (Gocke and Kavey, 1969; Hirschman et al., 1969), but they accord with the clinical experience that serum hepatitis is an uncommon disease in Australia and Great Britain (Cossart, 1969), where blood donors are volunteers.

Despite the regional variations in prevalence, the presence of $\mathrm{Au}$ (1) antigen in the serum of some patients with chronic hepatitis adds to the likelihood that viral hepatitis, occasionally at least, precedes and leads on to active chronic hepatitis and cirrhosis. We recall that 3 out of 25 patients with lupoid hepatitis and 4 out of 25 patients with active chronic hepatitis in this unit gave a definite history of hepatitis contact shortly before the onset of their illness (Mackay et al., 1965); other evidence bearing on this was cited by Mackay (1968). On the other hand, viral hepatitis antigen $\mathrm{Au}$ (1), as detected by immunoprecipitation, occurred too infrequently in our study to be regarded as essential for the chronicity of active chronic hepatitis and lupoid hepatitis, the conclusion also reached in the London study of Fox et al. (1969). 
The age incidence of Au (1) antigen in hepatitis is of interest. Each of the Au (1)-positive subjects in our present study who was a patient in this unit (Cases 1,2 , and 5 , Table II) was over the age of 50. London et al. (1969) commented on the absence of $\mathrm{Au}$ (1) in young hepatitis patients in the U.S.A., and Gitnick et al. (1969) mentioned three patients with active chronic hepatitis who were positive for $\mathrm{Au}$ (1) but were men aged 75, 46, and 66 years; this age and sex distribution is unusual for active chronic hepatitis. A bimodal age distribution of 41 patients with lupoid hepatitis was described by Mackay (1968): most patients were girls or young women, but a proportion were males $(17 \%)$ or older women $(33 \%)$, and $40 \%$ were over the age of 40 . We suggest that Au (1)-positive cases of chronic hepatitis come from a subpopulation of older patients, and that active chronic hepatitis in this presumably susceptible older age group is attributable to initial infection with or breakdown of immunological tolerance to Au (1)-positive (long-incubation-period) hepatitis virus. In younger individuals, however, active chronic hepatitis might follow infection with the short-incubation-period hepatitis virus (Au (1)-negative) which is not yet demonstrable serologically.

\section{Appendix}

Case 1.-A woman aged 63 in 1961 had symptoms of hepatitis for three weeks. The serum gammaglobulin rose to $4.7 \mathrm{~g} . / 100 \mathrm{ml}$. The test for L.E. cells was strongly positive. Liver biopsy showed active hepatitis with some distortion of architecture (Fig. 1).

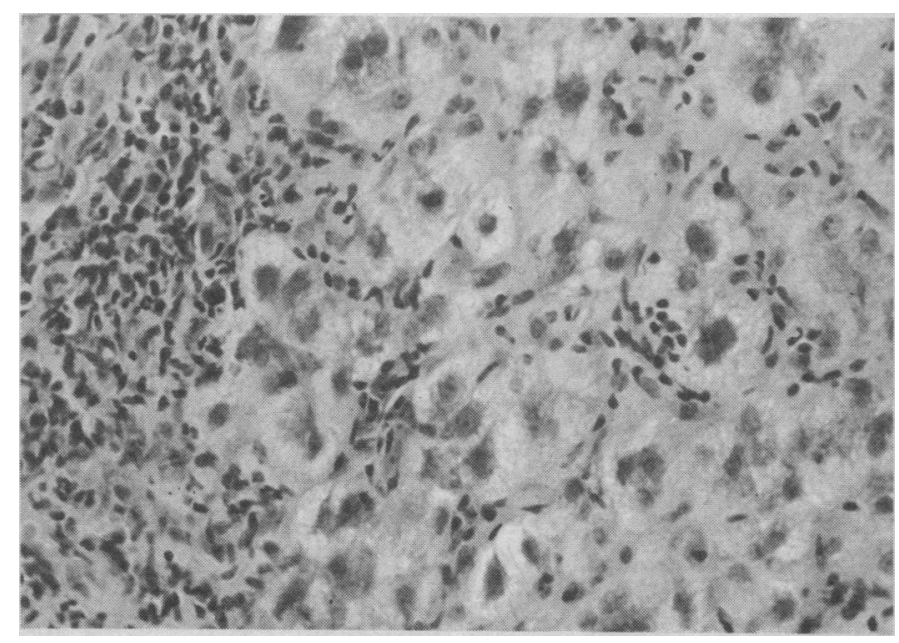

Fig. 1.-Case 1. Liver biopsy showing "ballooned" and vacuolated liver cells, "rosettes," lobular invasion by fibroblasts, and portal reaction: active chronic hepatitis. (Haematoxylin and eosin. $X$ 270.)

Prednisolone and later azathioprine induced pronounced improvement (Mackay and Wood, 1963; Case 22, Fig. 5). Liver biopsies in 1964 and 1968 showed quiescent active chronic hepatitis with prominence of plasma cells. Tests for smooth-muscle antibody were negative, for antinuclear factor positive but only to granulocyte nuclei, and for antimitochondrial antibody positive. All of 14 available serum specimens (from December 1965 to July 1969) contained Au (1) antigen.

Case 2.-A mortuary attendant aged 55 in 1966 presented with symptoms of hepatitis for $\mathbf{1 0}$ days. He had had jaundice five years previously. He had carried out a necropsy on a patient who had died from fulminant hepatitis two months earlier. The maximum level of serum gammaglobulin was $2.4 \mathrm{~g} . / 100 \mathrm{ml}$. The liver biopsy was interpreted as active chronic hepatitis (Fig. 2). Prednisolone induced some but not full improvement. Tests for L.E. cells and

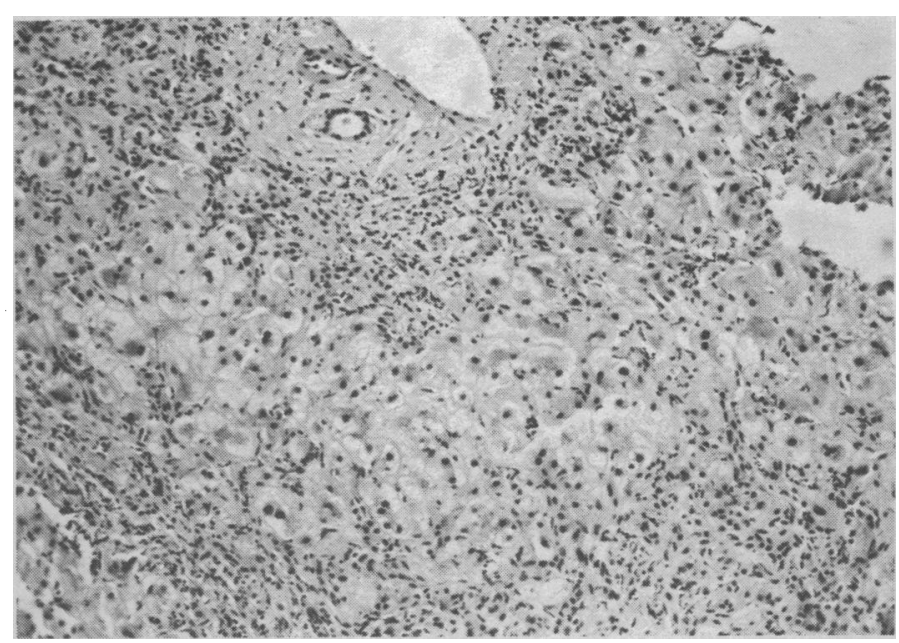

FIG. 2.-Case 2. Liver biopsy showing fibrosis with disruption of architecture, "piecemeal necrosis" in perilobular region, and moderate cellula reaction: active chronic hepatitis. (Haematoxylin and eosin. $X$ 85.)

smooth-muscle antibody were negative and tests for antinuclear factor became weakly positive. Au (1) antigen was found in all eight specimens tested.

We thank Sir Macfarlane Burnet, Dr. Senga Whittingham, and Dr. I. J. Wood for their advice, and Dr. A. A. Ferris, Mr. J. Kaldor, Dr. R. Lucas, Professor R. A. Joske, Dr. L. Williams, Dr M. Davey, and Dr. P. Kincaid-Smith for referring sera and providing details of diagnoses. Dr. T. B. Reynolds kindly allowed us to cite his case of posttransfusion cirrhosis. Dr. B. Blumberg and Dr. Y. Cossart provided reference antigens and antisera, and Dr. Blumberg's laboratory kindly confirmed the presence of Au (1) in our positive sera. Miss Jane Allardice provided valuable technical assistance. Both of us were supported by a grant from the National Health and Medical Research Council of Australia.

REFERENCES

Bayer, M. E. Blumberg, B. S, and Werner, B. (1968). Nature, 218, 1057 Blumberg. B. S. Alter, H. J and Visnich. (1965). fournal of the American Medical Association, 191, 541.

Blumberg, B. S., Gerstley, B. J. S., Hungerford, D. A., London, W. T. and Sutnick, A. I. (1967). Annals of Internal Medicine, 66, 924.

Blumberg, B. S., Sutnick, A. I., and London, W. T. (1968). Bulletin of the New York Academy of Medicine, 44, 1566.

Cossart, Y. E. (1969). Lancet, 1, 1216.

Fox, R. A., Niazi, S. P., and Sherlock, S. (1969). Lancet, 2, 609.

Giles, J. P., McCollum, R. W., Berndtson, L. W., and Krugman, S. (1969). New England fournal of Medicine, 281, 119.

Gitnick, G. L., et al. (1969). Lancet, 2, 285.

Gocke, D. J., and Kavey, N. B. (1969). Lancet, 1, 1055.

Hirschman, R. J., Shulman, N. R. Barker, L. F, and Smith, K. O (1969). Fournal of the American Medical Association, 208, 1667.

Krugman, S., Giles, J. P., and Hammond, J. (1967). Fournal of the American Medical Association, 200, 365.

London, W. T., Sutnick, A. I., and Blumberg, B. S. (1969). Annals of Intermal Medicine, $70,55$.

Mackay, I. R. (1968). Bulletin on Rheumatic Diseases, 18, 487.

Mackay, I. R., Weiden, S., and Hasker, J. (1965). Annals of the New York Academy of Sciences, 124, 767.

Mackay, I. R., and Wood, I. J. (1963). Gastroenterology, 45, 4.

Okochi, K., and Murakami, S. (1968). Vox Sanguinis, 15, 374.

Prince, A. M. (1968a). Proceedings of the National Academy of Sciences of the United States of America, 60, 814 .

of the United States of America, 60
Prince, A. M. (1968b). Lancet, 2, 462 .

Turner, G. C., and White, G. B. B. (1969). Lancet, 2, 121.

Wright, R., McCollum, R. W., and Klatskin, G. (1969). Lancet, 2, 117. 